\title{
DETERMINANTS OF MOTHERS' PARTICIPATION IN ANTENATAL CLASSES
}

\author{
Determinan Keikutsertaan Ibu dalam Kelas Ibu Hamil \\ Sutopo Patriajati ${ }^{1},{ }^{\star}$ Ayun Sriatmi ${ }^{2}$ \\ 1,2Faculty of Public Health, Diponegoro University, Indonesia \\ ${ }^{*}$ Correspondence: ayunsriatmi@gmail.com
}

\begin{abstract}
Background: As a form of health promotion, Antenatal Education (AE) class is expected to improve the knowledge, attitudes, and practices of mothers facing their pregnancy. Access to antenatal classes for mothers has not been optimal because of the low level of participation. Not all mothers are willing to join antenatal classes for various reasons.

Aim: This study aimed at analyzing the determinant factors that influence the mother's participation in antenatal classes.

Method: This study was a quantitative study with a cross-sectional approach. The population was all pregnant women in Semarang City with 140 pregnant mothers as samples from 3 Primary Healthcare Centers including Rowosari, Purwoyoso, and Gayamsari which were selected by using a purposive sampling technique. Data were collected through an interview using a structured questionnaire.

Results: The findings showed that only $54.3 \%$ of mothers attended the antenatal classes. Knowledge, support from health personnel, facilities, and infrastructure, as well as a history of illness and pregnancy, affect mothers' participation in antenatal classes where the support of health workers had the most dominant influence (OR 5.394). The overall influence was $39.2 \%$.

Conclusion: The low mothers' participation in antenatal classes was influenced by the lack of knowledge and support, inadequate facilities as well as the low health status of mothers. Further socialization and engagement across related sectors with strong networking are needed to solve this problem.
\end{abstract}

Keywords: antenatal education, participation, primary healthcare center.

\section{ABSTRAK}

Latar Belakang: Sebagai bentuk promosi dan pendidikan kesehatan, Kelas lbu Hamil diharapkan mampu meningkatkan pengetahuan, sikap dan praktek ibu menghadapi kehamilannya. Akses ibu hamil terhadap Kelas Ibu Hamil belum optimal karena tingkat kepesertaan rendah. Tidak semua ibu mengikuti Kelas Ibu Hamil dengan berbagai alasannya.

Tujuan: Menganalisis faktor determinan yang mempengaruhi keikutsertaan dalam Kelas Ibu Hamil.

Metode: Penelitian survei dengan pendekatan kuantitatif dan bersifat cross sectional. Populasi semua ibu hamil di kota Semarang dan sampel 140 ibu hamil dari 3 Pusat Kesehatan Masayarakat (Puskesmas) terpilih (Rowosari, Purwoyoso dan Gayamsari) menggunakan teknik purposive sampling. Pengumpulan data melalui wawancara menggunakan kuesioner terstruktur, yang dianalisis secara univariat, bivariat dan multivariat menggunakan regresi logistik berganda.

Hasil: Hanya 54,3\% ibu yang mengikuti Kelas Ibu Hamil. Pengetahuan, dukungan tenaga kesehatan, fasilitas \& sarana prasarana, serta riwayat penyakit dan kehamilan terbukti secara bersama-sama mempengaruhi keikutsertaan ibu dalam $\mathrm{KIH}$, dimana dukungan tenaga kesehatan paling dominan pengaruhnya $(O R$ 5,394). Besar pengaruh keseluruhan 39,2\%.

Kesimpulan: Rendahnya keikutsertaan ibu dalam Kelas lbu Hamil dipengaruhi rendahnya pengetahuan, dukungan yang kurang dan ketersediaan fasilitas Kelas Ibu Hamil yang dirasakan belum memadai serta riwayat kesehatan ibu hamil. Peningkatan sosialisasi dan pelibatan lintas sektor melalui penguatan jejaring sangat diperlukan untuk menjembatani masalah ini.

Kata kunci: kelas ibu hamil, keikutsertaan, puskesmas.

$\begin{array}{lll}\text { Received: } 17 \text { January } 2019 & \text { Accepted: } 4 \text { March } 2019 & \text { Published: } 23 \text { October } 2019\end{array}$

\section{INTRODUCTION}

Every pregnancy has several risks of dangerous complications. Death due to complications of pregnancy and childbirth can be avoided when mothers routinely check their pregnancy to detect the risk of complications that may occur (Agus and Horiuchi, 2012; Indonesian Ministry of Health, 2013; Indonesian Ministry of Health, 2015). Antenatal care (ANC) also prevents unexpected occurrence during pregnancy (Shrestha, Bell, and Marais, 2014). It can be an 
opportunity to identify various risks of pregnancy (Agus and Horiuchi, 2012; Indonesian Ministry of Health, 2013) and monitor health services for mothers from many potentially fatal pathological risks, such as HIV, anemia, malnutrition, tuberculosis, hepatitis, and malaria (Finlayson and Downe, 2013). The earlier the risk factors are known, the better handling mechanism of the risk factors is.

Like other developing countries, the utilization of antenatal services in Indonesia is not optimal. From the Indonesian Health Profile in 2016 , it was found that coverage of K1 (first visit) and K4 (fourth visit) was $92.3 \%$ and $85.35 \%$ which illustrates that not all pregnant women use ANC services (Indonesian Ministry of Health, 2017). Not only do the factors of access affect the low utilization of ANC, but also the level of mothers' knowledge and attitudes do. Non-compliance with ANC examination standards has an impact on the higher risk factors to detect inaccurate complications which ultimately lead to an increased risk of maternal death (Indonesian Ministry of Health, 2014)

Antenatal classes are solutions to overcome the knowledge constraints about pregnancy care and complication risks. This activity is integrated with the maternal health services provided by the government (Runjati et al., 2017). The main objective is to enhance knowledge, skills, changed attitudes and behavior, as well as shared learning for pregnant women in groups. The activity is also oriented to improve maternal compliance in routine antenatal care visits. On the other hand, Antenatal classes also have a community empowerment principle because it involves the role and participation of pregnant women. The success of antenatal classes is determined by how many pregnant women attend and get involved in various activities.

In some countries, antenatal classes have managed to meet participants' expectations. Most participants $(96 \%$ of pregnant women and $92 \%$ of husbands) in Sweden considered antenatal classes helpful for more secure feelings as parents and childbirth preparation (Ahldén et al., 2012). Through structured interventions with interactive modules by facilitators, antenatal education activities in Laos increased an average mothers' knowledge and understanding about basic care for a newborn of $10 \%$ for low-educated mothers (Weiner et al., 2011). McMillan in Tomintz et al. (2013) stated that through antenatal classes, a material review could be provided comprehensively in more detail according to mother's antenatal condition. Qualitative research by Nolan et al. (2012) also showed that the existence of antenatal classes is very helpful in increasing parents' self-confidence and establishing friendships and at the same time creating new social networking (Tomintz et al., 2013).

In Indonesia, research in Bogor City showed the relationship of maternal participation in Antenatal Education class with better knowledge and positive attitude in recognizing the danger signs of pregnancy (Sasnitiari et al., 2017). The Antenatal Education class also proved as a dominant factor in increasing antenatal visits in South Lampung
(Xanda, 2015). Research in Kendal District proved that the participation in Antenatal Education class was related to knowledge and attitudes, yet it was not related to the practice of postpartum care (Khafidzoh,Rahfiludin and Kartasurya, 2016). Research in Primary Healthcare Center of Kedungmundu in Semarang City also showed that participation and family social support in Antenatal Education class are related to exclusive breastfeeding behavior, and husband's social support is the most dominant factor (Pertiwi, Suyatno, and Dharminto., 2017).

Although antenatal classes provide significant benefits to enhance pregnant women's knowledge, attitudes, and practices. The facts show that the existing $A E$ has not been optimal in bridging the needs and expectations of pregnant women. It is proven by the high mothers' reluctance in attending regularly all $\mathrm{AE}$ activities. The average maternal presence in antenatal classes was around middle range of $60 \%-65 \%$ or even less (Khafidzoh, Rahfiludin, and Kartasurya, 2016; Pradany and Margawati, 2016). The pregnant women's reluntance to follow antenatal classes routinely becomes one of indications that $A E$ is not a mother's need. Only $30 \%$ of antenatal class activities run well in Malang City (Kusbandiyah, Kartasurya, and Nugraheni, 2013) A total antenatal class of $39.68 \%$ in Purbalingga District had poor performance (Sari, 2017). The level of cadres' participation in class activities was also less active about $47.7 \%$. (Agustinawati, Husodo, and Musthofa, 2017). There is a relationship between mother's knowledge and attitudes, motivation, husband's support and family support for participation in the Antenatal Education classes (Septiani, 2013; Astuti, Sofiyanti, and Widyaningsih, 2016; Widiantari, Suariyani, and Karmaya, 2016).

Semarang City had the largest maternal mortality rate (MMR) in 35 districts of Central Java with 32 cases in 2016 (MMR 121.5 per 100,000 life births) (Province Health Office of Central Java, 2016). In 2017, a total of 271 antenatal classes were held and attended by around 7-12 participants in each class, while the number of pregnant women was 28,758 spread across 37 Primary Healthcare Centers (District Health Office of Semarang, 2018). The proportion of pregnant women's participation in antenatal classes was only around $10 \%$ from the population of pregnant mothers in Semarang City. By interviewing midwife coordinators during the preliminary survey, it was found that classes and learning materials were also not optimal because of many mothers who did not routinely attend the learning.

Research on factors influencing mother's participation in Antenatal Education class in Semarang city has never been done yet. Studies that illustrate the overall factors influencing the mother's participation in Antenatal Education classes as a whole are also rare, and they generally only look at predisposing and enabling factors. Therefore, this study aims to analyze various factors that influence mother's participation in Antenatal Education classes, not only from predisposing and enabling factors but also from components of their needs. 


\section{METHOD}

This research was a quantitative study with a cross-sectional design. Adopted to the model of Andersen's health utilization (Abraham and Sheeran, 2005), the independent variables of the study were divided into 3 components, such aspredisposing factors (knowledge, attitude, and parity), enabling factors (access to health facilities, environmental, family and community support, health personnel support, regulation, facilities, and infrastructure), need factors (history of disease and pregnancy, perception of pregnancy status, the number of pregnancy complaints from mothers, and perceived level of danger). Dependent variables were antenatal class participation. In this study, maternal characteristics (mothers' age, gestational age, education, employment, ownership of health insurance and family income) were included as control variables.

The research population was a total of pregnant women in Semarang City. The samples were determined by using purposive sampling based on the primary healthcare centers which actively organize antenatal classes but had the highest number of maternal mortalities, the least and without maternal mortality cases in the last 3 (three) years in representative areas of Semarang City. Selected primary healthcare centers included Primary Healthcare Center of Gayamsari, Primary Healthcare Center of Purwoyoso and Primary Healthcare Center of Rowosari. Each Primary Healthcare Center was represented by 2 (two) villages which were opted randomly. Using a minimum sample formula, 140 pregnant women were involved as respondents and taken accidentally. The number of respondents in each Primary Healthcare Center was determined proportionally based on the number of pregnant women in the villages.

Primary data were collected through interviews with structured questionnaires that validity and reliability have been tested. The analysis was carried out descriptively and statistically by Chi-Square test for the relationship test and Multiple Logistic Regression to see which variables are the most dominant in influencing mothers' participation in antenatal class through OR (Odd-Ratio) value. Variables in multivariate modeling were variables from the bivariate test had p-value $<0.25$.

\section{RESULTS AND DISCUSSION}

Based on the respondents' characteristics, it is noticeable that most mothers have an ideal age for pregnancy and childbirth around 20-30 years with a current gestational age of $\geq 4$ months (second and third trimesters). Generally, they have $\leq 2$ children. Compared to the education category, the number of mothers with secondary education (high school level) was higher, and most of them are housewives. The average family income per month is already above the Minimum District Wages of Semarang City (IDR 2,300,000), and they have health insurance, especially from the Social Security Agency for Health.

There are 140 pregnant women, only $54.3 \%$ attended antenatal classes. These results were the same as various studies which the average mothers' attendance and participation for Antenatal Education were only in the middle range about $60.4 \%$ or even less (Masini, 2015; Pradanyand Margawati, 2016). In the other study explained a level of maternal participation in antenatal class was only 52.8\% (Murwati, Suryani and Kurniawati, 2018). It was also proven by Kusbandiyah, Kartasurya and Nugraheni's study (2013) in Malang City where the well-implemented antenatal classes were only about 30\%. Some reasons for absenteeism are housework, inappropriate schedule, childbearing, no idea about the program, nobody accompanying mothers, routine pregnancy checks by medical specialist, reluctance to attend, laziness, having perception about their healthy pregnancy, and less attractive and mundane materials. The reasons given were generally the same as the study of Boerleider et al. (2013) that found non-western ethnic pregnant women in Sweden did not join antenatal classes for work reasons (night shift), lack of interest, transportation constraints, inflexible boss' attitudes, and absence of partners or husbands.

The presence and participation of pregnant women in antenatal classes are a form of community's participation. On the other hand, community's participation is the key success of maternal health programs because the community are the subject and object of this program. The efforts to increase community's participation require a supportive policy to increase their understanding of maternal health problems as a shared responsibility (Howard-Grabman et al., 2017). Therefore, the program must be able to identify what mothers want and need in the antenatal classes. A study conducted by Almalik and Mosleh (2017) outlined some important materials needed by pregnant women, such as the main causes of pregnancy complications, routine monitoring and follow-up visits to mothers during pregnancy, proper diet and information about medications and supplements.

The results showed that most of the mothers had low knowledge (64.3\%), especially knowledge about pregnancy and childbirth. Educational factors and occupational factors as housewives contribute to low knowledge because mothers must routinely do domestic work (household). The percentage of support from health workers in good and strong category was $50.7 \%$ while the mothers who received poor health staff's support was $49.3 \%$. In terms of material and infrastructure, pregnant women who found inadequate infrastructures are slightly higher in $50.7 \%$ than those who thought that the facilities are adequate. There were $61.4 \%$ of mothers experiencing various complaints in their current pregnancies with various levels of complaints. However, those who considered the complaints are less dangerous were amounted to $55 \%$ compared to those who thought that the complaints were dangerous. For other variables, in general, in the mothers gave a good and positive 
response (see Table 1).Based on the descriptive analysis, the low participation of antenatal classes is caused by low knowledge, weak support, and inadequate availability of materials and infrastructures. The partial analysis with Chi-Square statistical tests proves that knowledge, family's and community's support, health workers' support, regulations, and infrastructures are significantly related to the pregnant women's participation in antenatal classes with $\mathrm{p}$-value $<0.05$.

By adopting the utilization model of health services from Andersen, this study shows that enabling factors are important elements in strengthening pregnant women's participation in antenatal classes. The findings of the study indicate that the availability of enabling factors is a possible prerequisite for the program implementation in facilitating and encouraging pregnant women's behaviors to participate in antenatal classes. In accordance with the statement of Stirman et al. (2012), the program sustainability is influenced by organizational factors, capacity, processes, and all aspects related to the program itself, including its innovation (adaptability and effectiveness)

Table 1. Analysis of Influential Variables on Mother's Participation in Antenatal Classes in Semarang City.

\begin{tabular}{|c|c|c|c|c|c|c|}
\hline \multirow[t]{2}{*}{ No } & \multirow[t]{2}{*}{ Variables } & \multirow[t]{2}{*}{ Categories } & \multirow[t]{2}{*}{ (\%) } & \multicolumn{2}{|c|}{$\begin{array}{l}\text { Participation in Antenatal } \\
\text { Education class }\end{array}$} & \multirow[t]{2}{*}{ P-value } \\
\hline & & & & No (\%) & Yes (\%) & \\
\hline \multirow[t]{2}{*}{1} & Knowledge & Low & 64.3 & 60 & 40 & $0.000^{\star}$ \\
\hline & & High & 35.5 & 20 & 80 & \\
\hline \multirow[t]{2}{*}{2} & Attitudes & Not good enough & 44.3 & 50 & 50 & 0.461 \\
\hline & & Good & 55.7 & 42.3 & 57.7 & \\
\hline \multirow[t]{2}{*}{3} & Parity & $\leq 2$ & 65 & 42.9 & 57.1 & 0.455 \\
\hline & & $>2$ & 35 & 51 & 49 & \\
\hline \multirow[t]{2}{*}{4} & Access to health & Difficult & 45.7 & 47.8 & 52.2 & 0.767 \\
\hline & facilities & Easy & 54.3 & 43.8 & 56.2 & \\
\hline \multirow[t]{2}{*}{5} & Environment & Not supportive & 28.6 & 52.5 & 47.5 & 0.406 \\
\hline & & Good & 71.4 & 43 & 57 & \\
\hline \multirow[t]{2}{*}{6} & Family's and & Weak & 42.9 & 66.7 & 33.3 & $0.000^{\star}$ \\
\hline & $\begin{array}{l}\text { community's } \\
\text { support }\end{array}$ & Strong & 57.1 & 30 & 70 & \\
\hline \multirow[t]{2}{*}{7} & Health workers' & Weak & 49.3 & 63.8 & 36.2 & $0.000^{\star}$ \\
\hline & support & Strong & 50.7 & 28.2 & 71.8 & \\
\hline \multirow[t]{2}{*}{8} & Regulation & Incomplete & 42.1 & 59.3 & 40.7 & $0.010^{*}$ \\
\hline & & Complete & 57.9 & 35.8 & 64.2 & \\
\hline \multirow[t]{2}{*}{9} & Materials and & Inadequate & 50.7 & 60.6 & 39.4 & $0.001^{*}$ \\
\hline & Infrastructures & Adequate & 49.3 & 30.4 & 69.6 & \\
\hline \multirow[t]{2}{*}{10} & History of illness & Dangerous & 47.9 & 37.3 & 62.7 & 0.082 \\
\hline & and pregnancy & Secure & 52.1 & 53.4 & 46.6 & \\
\hline \multirow[t]{2}{*}{11} & Perception of & Poor & 40.7 & 56.1 & 43.9 & 0.060 \\
\hline & pregnancy & Good & 59.3 & 38.6 & 61.4 & \\
\hline \multirow[t]{2}{*}{12} & Pregnancy & Many complaints & 61.4 & 48.8 & 51.2 & 0.446 \\
\hline & complaints & Few complaints & 38.6 & 40.7 & 59.3 & \\
\hline \multirow[t]{2}{*}{13} & Level of & High & 45 & 52.4 & 47.6 & 0.207 \\
\hline & $\begin{array}{l}\text { pregnancy } \\
\text { complaints }\end{array}$ & Less & 55 & 40.3 & 59.7 & \\
\hline
\end{tabular}

Although there is no statistical correlation between a history of illness and pregnancy with participation in antenatal classes, the descriptive picture shows interesting results. The results showed mothers with a history of pregnancy risks and illness are more likely to join antenatal class activities. On the other hand, mothers who had no history of pregnancy risks are more likely not to follow antenatal classes. It means that mothers who had pregnancy problems dominated in antenatal classes. Due to fear of greater risks, they tried to find a lot of information and support through antenatal classes to increase their self-confidence and self-efficacy.

This research is in line with the study of Sercekus and Baskale (2016) which stated that antenatal education reduces fear in labor because it simultaneously increases mothers' self-confidence (efficacy) towards pregnancy and childbirth as well as being a parent (Nolan et al., 2012). The study in Turkey conducted by Gökçe Isbir et al. (2016), also showed that pregnant women who attended antenatal education had a greater level of confidence in facing labor because they got better support and monitoring to reduce the fear and symptoms of postpartum stress that often occurred compared to what the control group felt.

Another interesting finding in this research is that the perception factor greatly influences mothers' participation in antenatal classes. Perception directs pregnant women's attitudes. Pregnant women who had fine-pregnancy perception tend to join antenatal classes, and mothers who had bad-pregnancy perception prefer not to join antenatal classes (not participating). 
These results contradict to the previous analysis that described mothers who attended antenatal classes were mostly those who had a history of illness and pregnancy. Even though they know they had a history of illness and pregnancy but thought their pregnancy is fine, they will tend to participate in antenatal classes. Conversely, even though mothers had no history of illness and pregnancy, but thought their pregnancy is not fine, they will not participate in antenatal class activities.

Cultural values and ethical factors are also related to the results of this study mother who experienced many normal and severe complaints during their current pregnancy tend to not attend antenatal classes. Meanwhile, mothers who had no complaints (only mild or fewer complaints) got involved actively in antenatal classes which are organized by primary healthcare centers. Sociocultural values that affect this condition include shame, reluctance, and self-esteem. Mothers feel ashamed if they are considered weak in facing their pregnancy because a mother is valued from the ability to face every problem in her pregnancy process.

In eastern culture and custom upheld by the community, mothers are often considered unethical, disrespectful and unwilling to disclose their pregnancy problems to others even to other pregnant women in antenatal classes that expect them to share information and experiences about their pregnancy. Pregnant women, families and even community have assumed that pregnancy is a natural condition and natural process. If a mother has a pregnancy complaint (dizziness, nausea, vomiting, swelling, etc.), it is considered as a normal thing. Mothers with complaints tend to stay quiet at home without trying to find treatments because they assume that those complaints would disappear with the increase in gestational age.

Multivariate analysis with multiple logistic regression (see Table 2) found that mothers' knowledge, support from health personnel, facilities, and infrastructure, history of illness and pregnancy simultaneously affect mothers' participation in antenatal classes. The health personnel's support became the dominant factor with a possibility of 5.394 times greater in increasing maternal participation (Odd-Ratio or OR value of 5.394), and the second dominant factor is mother's knowledge (OR value of 3.941). The third dominant factor is the availability of facilities and infrastructure (OR value of 3.313), and the fourth one is a history of illness and pregnancy (OR value of 2.831). Based on the $R^{2}$ value of 0.392 , it means that the effect of the four variables on maternal participation in antenatal classes is $39.2 \%$, and the rest $(60.8 \%)$ is influenced by other variables.

If mothers' knowledge is improved, the possible increase in participation in antenatal classes is 3.941 times greater. Also, if the infrastructures are well equipped, the maternal participation in antenatal classes will also increase by 3.313 times. Good understanding and positive perception about the history of disease and pregnancy also have a possible increase of 2.831 times greater in antenatal class.

Table 2. Multivariate Analysis of Determinant Factors on Mother's Participation in Antenatal Education class in Semarang City.

\begin{tabular}{lcccccccc}
\hline \multicolumn{1}{c}{ Variables } & B & S.E. & Wald & df & p-value & Odds-Ratio & Lower & Upper \\
\hline Knowledge & 1.371 & 0.458 & 8.961 & 1 & 0.003 & 3.941 & 2.395 & 12.872 \\
\hline Health workers' support & 1.685 & 0.440 & 14.692 & 1 & 0.000 & 5.394 & 2.038 & 11.970 \\
\hline $\begin{array}{l}\text { Materials and } \\
\text { Infrastructures }\end{array}$ & 1.198 & 0.417 & 8.266 & 1 & 0.004 & 3.313 & 1.429 & 7.682 \\
\hline $\begin{array}{l}\text { History of illness and } \\
\text { pregnancy }\end{array}$ & 1.041 & 0.445 & 5.470 & 1 & 0.019 & 2.831 & 1.765 & 5.973 \\
\hline $\begin{array}{l}\text { Constanta } \\
\text { *Source: Primary Data }\end{array}$ & -2.151 & & & & & & & \\
\hline
\end{tabular}

The support from health workers as the dominant factor for pregnant women's participation in antenatal classes is valued from the management of the pregnancy and childbirth process. Health workers (especially midwives) become the first reference for pregnant women who experience pregnancy problems. That kind of trust must be managed well by giving encouragement and support continuously. According to Nasir, Amran and Nakamural. (2017), prenatal education or antenatal education strengthens the interaction between pregnant women and healthcare providers (including health workers) as well as maternal knowledge and practice for pregnancy care, childbirth, and newborn care.

This study is similar to another study which stated that perceptions on the health workers' attitudes are the dominant factor to predict the use of primary healthcare centersas gatekeepers in Bekasi City (Wulandari and Achadi, 2017). Another study in Ethiopia also proved there is a relationship between health workers and antenatal care, knowledge of pregnancy danger signs and other demographic factors (Birmeta, Dibaba, and Woldeyohannes, 2013).

Good communication and good health workers' attitudes will lead to mothers' positive perceptions in receiving or utilizing health services, including participating in antenatal classes. Boerleider etal. (2013) proved that communication factors became one of the obstacles for prenatal class participation in non-Western (European) pregnant women. Moreover, terms delivered by midwives or facilitators should be in accordance with community language to easily understand.. The use of everyday language or community language is 
one effective way to convey important information and materials to avoid misunderstandings and confusion. An effective pattern of communication is also carried out in every process of socialization for mother, family, and community as a part of learning process and interaction with the environment.

Participation in antenatal classes will get better if it is followed by efforts to strengthen mothers' knowledge and adequate infrastructures. Good knowledge about pregnancy increases the ability to identify various risk factors for complications and predictions through a history of illnesses and previous pregnancies. Awareness of pregnancy status brings mothers to more routine contact with health workers to find problem solutions and prevention efforts to be done.

Although there was no significant relationship between the history of illness and pregnancy and the participation in antenatal classes by partial test, the output of multivariate tests proved the effect of this variable to the participation of antenatal classes when combined with other variables, especially mother's knowledge.

The more mother's knowledge about pregnancy and childbirth is, the more mothers understand and are able to identify a history of illness and pregnancy that are potential to endanger the pregnancy. It also increases awareness to conduct routine antenatal checks and utilize all activities related to the detection and prevention of risk factors.

Information needs to be disseminated continuously to solve confusion, misunderstanding or misinformation. Information access and socialization especially in antenatal classes can be expanded through cross-sectoral support and involvement of local leaders, such as Family Welfare Guidance or Pembinaan Kesejahteraan Keluarga (PKK), Dasa Wisma (A group of mothers from ten householders living nearby), religious leaders, community leaders, community organizations, NGOs, regional officials, and so on. Also, family roles can also be improved and empowered through the support of husbands and/or parents.

The implementation of antenatal classes also cannot take place if necessary materials and infrastructures are absent. Although the materials of antenatal classes are given based on the Maternal and Child Health (MCH) Handbook or Buku Kesehatan Ibu dan Anak which is a guide for every pregnant woman in Indonesia, the learning process will be better and more attractive if it is equipped with sufficient CIE (Communication, Information \& Education) teaching aids. The needs for other materials and facilities should also be fulfilled, such as representative rooms, good audio-visual aids, and learning materials and discussions tailored to the group's needs.

The results of this study are in line with the research of Fuada and Setyawati (2015) proved that the success of antenatal classes was determined by facilitators' potential and support, government's support, and mothers' interests in learning materials of antenatal classes. Social support from husbands is the most dominant factor in increasing the participation of pregnant women in antenatal classes despite maternal education factors, family parity and income (Widiantari, Suariyani and Karmaya, 2016). According to Ahlden et al. (2012), maternal classes should be more attractive and interesting so that they can meet participants' expectations and readiness to be "perfect parents" later.

Building positive perceptions about antenatal classes is a key factor in increasing maternal participation in antenatal classes conducted by primary healthcare centers. Perception is a psychological process that affects the mindset or mind mapping and learning processes of a subject. The source of perception comes from knowledge, experience, thoughts, feelings, and attention faced by mothers from the environment. Problems caused by misperception will result in bad social relations and social interaction. Several ways to build good perceptions include respecting others' opinions, seeing things from many perspectives, becoming a good listener, learning how to argue and taking an initiative. Besides, good perceptions also come from the ability to have good interpersonal communication, have a considerable conclusion, receive processed information, and use the process of intra-personal thinking.

Reducing gaps that focus on various issues of physical, psychological and emotional status and risks of possible complications must be anticipated by national programs through the development of antenatal education models based on mothers' perceptions of pregnancy (Almalik and Mosleh, 2017) and program and content development (Serçekuş and Başkale, 2016).

\section{CONCLUSION}

Low participation of pregnant women in antenatal classes are influenced by the low level of knowledge, the health worker's support, the availability of facilities and infrastructures, as well as the history of illness and the history of previous pregnancies. Health worker's support is the most dominantly influential factor. Building mothers' positive perceptions of antenatal classes is the key to successful implementation. Support from health workers through persuasive communication, mentoring, and empathy models can motivate mothers to participate in Antenatal Education classes. Primary Healthcare Centerscan provide training on healthcare to $\mathrm{MCH}$ officers. In addition, the mechanism of routine visits can also be improved.

Organizers of health programs (especially $\mathrm{MCH}$ programs) need to conduct more intensive socialization by using attractive and interesting media for health promotion. Also, they need to routinely advocate facility support for community leaders, such as regional officials, religious leaders, and local community leaders. Antenatal classes based on community empowerment needs to be done. Community empowerment is a basic instrument to assess the performance of $\mathrm{MCH}$ programs, which one of the benchmarks is regular participation of pregnant women in antenatal classes. Also, regional health teams should be more active in attending the structured training, and they 
should have clear division of labor and reward systems. Mechanisms for supervision, monitoring, and evaluation must also be developed regularly to ensure the implementation quality of antenatal classes.

\section{CONFLICT OF INTEREST}

The authors state that there is no conflict of interest for this article.

\section{REFERENCES}

Abraham, C. and Sheeran, P. (2005) 'The Health Belief Model', in Predicting Health Behaviour. Chapter 2.

Agus, Y. and Horiuchi, S. (2012) 'Factors influencing the use of antenatal care in rural West Sumatra , Indonesia', BMC Pregnancy and Childbirth, 12(9), pp. 1-8. doi: https://doi.org/10.1186/1471-2393-12-9.

Agustinawati, L., Husodo, B. T. and Musthofa, S. B. (2017) 'Faktor-Faktor Yang Berhubungan Dengan Partisipasi Kader Dalam Penyelenggaraan Kelas lbu Hamil di Kelurahan Ngesrep Kota Semarang', Jurnal Kesehatan Masyarakat (e-Journal), 5(5).

Ahldén, I. et al. (2012) 'Parents' expectations about participating in antenatal parenthood education classes.', The Journal of perinatal education, 21(1), pp. 11-17. doi: 10.1891/1058-1243.21.1.11.

Almalik, M. M. A. and Mosleh, S. M. (2017) 'Pregnant women: What do they need to know during pregnancy? A descriptive study', Women and Birth, 30(2), pp. 100-106. doi: 10.1016/j.wombi.2016.09.001.

Astuti, W. W., Sofiyanti, I. and Widyaningsih, A. (2016) 'Faktor-Faktor Yang Berhubungan Dengan Keikutsertaan Mengikuti Kelas Ibu Hamil Di Puskesmas Candiroto Kabupaten Temanggung', in RAKERNAS AIPKEMA 2016. Semarang: Universitas Muhammadiyah Semarang.

Birmeta, K., Dibaba, Y. and Woldeyohannes, D. (2013) 'Determinants of maternal health care utilization in Holeta town, central Ethiopia', $B M C$ health services research, 13(256), pp. 1-10. doi: 10.1186/1472-6963-13-256.

Boerleider, A. W. et al. (2013) 'Factors affecting the use of prenatal care by non-western women in industrialized western countries: a systematic review', BMC Pregnancy Childbirth, 13(81), pp. 1-11. doi: 10.1186/1471-2393-13-81.

District Health Office of Semarang (2018) Profil Kesehatan Kota Semarang Tahun 2017. Semarang: Dinas Kesehatan Kota Semarang. Available at: http://dinkes.semarangkota.go.id/asset/uploa d/Profil/Profil/Profil.

Finlayson, K. and Downe, S. (2013) 'Why Do Women Not Use Antenatal Services in Lowand Middle-Income Countries? A MetaSynthesis of Qualitative Studies', PLoS Medicine, 10(1), pp. 1-12. doi: 10.1371/journal.pmed.1001373.
Fuada, N. and Setyawati, B. (2015) 'Pelaksanaan Kelas Ibu Hamil di Indonesia', Jurnal Kesehatan Reproduksi, 6(2). doi: 10.22435/kespro.v6i2.4745.67-75

Gökçe İsbir, G. et al. (2016) 'The effects of antenatal education on fear of childbirth, maternal self-efficacy and post-traumatic stress disorder (PTSD) symptoms following childbirth: an experimental study', Applied Nursing Research, 32, pp. 227-232. doi: 10.1016/j.apnr.2016.07.013

Howard-Grabman, L. et al. (2017) 'Factors affecting effective community participation in maternal and newborn health programme planning, implementation and quality of care interventions', BMC Pregnancy and Childbirth, 17(268), pp. 1-18. doi: 10.1186/s12884-017-1443-0.

Indonesian Ministry of Health (2013) Buku Saku Pelayanan Kesehatan lbu Di Fasilitas Kesehatan Dasar Dan Rujukan. Jakarta: Indonesian Ministry of Health.

Indonesian Ministry of Health (2014) 'Mother's Day, Situasi Kesehatan Ibu', Infodatin. Available at:

http://www.depkes.go.id/resources/download /pusdatin/infodatin/infodatin-ibu.pdf.

Indonesian Ministry of Health (2015) Profil Kesehatan Indonesia Tahun 2014. Jakarta.

Indonesian Ministry of Health (2017) Profil Kesehatan Indonesia Tahun 2016. Jakarta.

Khafidzoh, A., Rahfiludin, M. Z. and Kartasurya, M. I. (2016) 'Hubungan Keikutsertaan Kelas Ibu Hamil dengan Perilaku Ibu dalam Perawatan Masa Nifas (Studi di Puskesmas Cepiring Kabupaten Kendal)', Jurnal Kesehatan Masyarakat (e-journal), 4(3), pp. 147-157.

Kusbandiyah, J., Kartasurya, M. I. and Nugraheni, S. A. (2013) 'Analisis Implementasi Program Kelas Ibu Hamil oleh Bidan Puskesmas di Kota Malang', Jurnal IImiah Kesehatan Media Husada, 2(1), pp. 1-9. doi: 10.33475/jikmh.v2i1.94.

Masini, M. (2015) 'Pengaruh Gravida, Pekerjaan, Dukungan Suami, Dukungan Bidan/Tenaga Kesehatan Terhadap Partisipasi Ibu Dalam Kelas Ibu Hamil Di Kabupaten Magelang', Jurnal Kebidanan, 4(8), pp. 37-44. doi: 10.1029/GL003i010p00589.

Murwati, Suryani, E. and Kurniawati, I. (2018) 'Relationship of Pregnant Women Classroom with Level of Anxiety with Labor to Pregnant Woman Trimester III in Jogonalan II Public Health Center Area', Journal of Midwifery, 3(1), pp. 1-5. doi: 10.25077/jom.1.1.15.2018.

Nasir, N. M., Amran, Y. and Nakamura, Y. (2017) 'Changing knowledge and practices of mothers on newborn care through mother class: An intervention study in Indonesia', Journal of Tropical Pediatrics, 63, pp. 440446. doi: $10.1093 /$ tropej/fmx010.

Nolan, M. L. et al. (2012) 'Making friends at antenatal classes: a qualitative exploration of friendship across the transition to motherhood.', The Journal of perinatal education, 21(3), pp. 178-185. doi: 
10.1891/1058-1243.21.3.178.

Pertiwi, R., Suyatno and Dharminto (2017) 'Hubungan Keikutsertaan Kelas Ibu Hamil dan Dukungan Sosial Keluarga dengan Perilaku Pemberian ASI Eksklusif Di Wilayah Kerja Puskesmas Kedungmundu', Jurnal Kesehatan Masyarakat, 5(4), pp. 830-838.

Pradany, S. P. and Margawati, A. (2016) 'Hubungan antara tingkat kehadiran ibu di kelas ibu hamil dengan perilaku pemberian ASI Eksklusif', Jurnal Kedokteran Diponegoro, 5(4), pp. 1752-1759.

Province Health Office of Central Java (2016) Profil Kesehatan Provinsi Jawa Tengah Tahun 2016. Semarang: Dinas Kesehatan Provinsi Jawa Tengah.

Runjati et al. (2017) 'The effect of antenatal class plus coping skill training on the level of stress and childbirth self-efficacy', Advanced Science Letters, 23(4), pp. 3329-3333. doi: 10.1166/asl.2017.9125.

Sari, O. H. (2017) 'Hubungan Motivasi terhadap Kinerja Bidan Desa dalam Pelaksanaan Program Kelas Ibu Hamil di Puskesmas Kabupaten Purbalingga', in PROSIDING: Seminar Nasional dan Presentasi Hasil-Hasil Penelitian Pengabdian Masyarakat, pp. 215221.

Sasnitiari, N. N. et al. (2017) 'Hubungan Keikutsertaan Ibu dalam Kelas Ibu Hamil dengan Pengetahuan dan Sikap terhadap Tanda Bahaya dalam Kehamilan di Kota Bogor', Jurnal Kesehatan Repro, 8(2), pp. 175-185.

doi: 10.22435/kespro.v8i2.6424.175-185.

Septiani, R. (2013) 'Pengetahuan, Sikap Ibu Hamil dan Dukungan Suami dengan Keikutsertaan Ibu Hamil dalam Kelas lbu Hamil di Puskesmas Kota Metro Lampung DI PUSKESMAS KOTA METRO LAMPUNG', Jurnal Kesehatan, 4(2), pp. 408-415. doi: http://dx.doi.org/10.26630/jk.v4i2.85.

Serçekuş, P. and Başkale, H. (2016) 'Effects of antenatal education on fear of childbirth, maternal self-efficacy and parental attachment', Midwifery, 34, pp. 166-172. doi: 10.1016/j.midw.2015.11.016.

Shrestha, S., Bell, J. S. and Marais, D. (2014) 'An analysis of factors linked to the decline in maternal mortality in Nepal', PLoS ONE, 9(4), $\quad$ pp. 1-9. doi: 10.1371/journal.pone.0093029.

Stirman, S. W. et al. (2012) 'The sustainability of new programs and innovations: a review of the empirical literature and recommendations for future research', Implementation Science, 7(17), pp. 1-19. doi: 10.1186/1748-5908-717.

Tomintz, M. N. et al. (2013) 'Optimising the location of antenatal classes', Midwifery, 29(1), pp. 33-43. doi: 10.1016/j.midw.2011.10.010.

Weiner, E. A. et al. (2011) 'Antenatal education for expectant mothers results in sustained improvement in knowledge of newborn care', Journal of Perinatology, 31(2), pp. 92-97. doi: 10.1038/jp.2010.108.

Widiantari, N. K. N., Suariyani, L. P. and Karmaya,
M. (2016) 'Hubungan Karakteristik Sosio Demografi dan Dukungan Sosial Suami dengan Partisipasi lbu Mengikuti Kelas Ibu', Public Health And Preventive Medicine Archive, 4(1), pp. 67-74.

Wulandari, F. K. and Achadi, A. (2017) 'Analisis Karakteristik dan Persepsi Pengguna Pelayanan Terhadap Pemanfaatan Puskesmas Sebagai Gatekeeper di Dua Puskesmas Kota Bekasi Tahun 2016', Jurnal Ekonomi Kesehatan Indonesia, 2(1), pp. 3947. doi: 10.1002/stem.438.

Xanda, A. N. (2015) 'Faktor-Faktor Yang Berhubungan Dengan Kunjungan Antenatal Care (Di Puskesmas Candipuro Kabupaten Lampung Selatan Tahun 2014)', Jurnal Kebidanan Adila Bandar Lampung, 11(2), pp. 28-39. 